\title{
HET ONTWORPEN INTERNATIONAAL BUREAU TER PUBLICEERING VAN DOUANETARIEVEN.
}

De douanetarieven behooren tegenwoordig onder de belangrijkste factoren waarmede bij het internationaal handelsverkeer rekening moet worden gehouden; de hanilelaren, onverschillig waar zij zijn gevestigd, hebben er veel belang bij dat hun de gelegenheid geboden wordt zich zoo spoedig en volledig mogelijk op de hoogte te stellen der tariefwetgeving van de Staten waarmede zij in handelsbetrekking staan.

Op verschillende wijze wordt dan ook getracht aan die behoefte te voldoen. Zonder nog te spreken van particulicre uitgaven op dit gebied, hebben de regeeringen der meeste Staten zich ten taak gesteld, de mededeelingen op douanewetgeving betrekking hebbende, door tusschenkomst van gezanten of consuls ter harer kennis gebracht, zoo spoedig mogelijk aan den handel mede te deelen.

Gelijk bekend is worden dergelijke berichten hier te lande in de Staats-Courant opgenomen, eene wijze van bekenimaking die het voordeel heeft dat de spoed er door gediend wordt; doch uit die verspreide berichten op een gegeven oogenblik een geheel te maken, zal, gesteld dat het mogelijk zij, niet dan met veel moeite en tijdverlies kunnen geschieden.

Andere landen, bv. Duitschland, Oostenrijk, Frankrijk, Italie, Zwitserland en Spanje hebben atn een der Departementen van Algemeen Bestuur bepaalde Bureaux ingericht, die voortdurend met het bijwerken der verschil- 
lende tarieven belast zijn, ten einde dic, vooral met het ong op de nationale belangen uit te geven.

In Belgie wordt gedeeltelijk het hier in gebruik zijnde stelsel gevolgd.

De (Moniteur Belge» bevat dagelijks tal van tariefmerledeelingen, doch daarnevens worden achtereenvolgens in de "Collection des tarifs douaniers" als bijvoegsel tot dat blad, de douanetarieven der verschillende landen, geheel bijgewerkt, opgenomen.

In Engeland vindt alles wat op den handel betrekking heeft natuurlijk eene eerste plaats in "The Board of Trade Journal " dat nu sedert twee jaar in gelijken geest doch beknopter vorm dan het (Deutsches Handelsarchiv) verschijnende, meer en meer een vraagbaak voor handel en nijverheid wordt.

Uit dit korte overzicht moge blijken dat allerwege op meer of minder volledige en practische wijze, de handel met dien factor, zoo onmishaar voor het aanknoopen en onderhouden van relaties met den vreemde, wordt bekend gemaakt.

De Belgische Regeering wenscht thans te trachten, om, waar zoovele landen één zelfle behoefte hebben te bevredigen, door samenwerking gemakkelijker, minder kostbaar en vollediger te verkrijgen wat thans elke Staat voor zich, met opoffering van veel tijd en geld moet tot stand brengen; meer dan door hetgeen de verschillende regeeringen afzonderlijk op dit gebied doen, zou, meent het Belgisch Gouvernement, elks belang gebaat worden door de oprichting van een Internationaal Bureau dat, voor gemeenschappelijke rekening onderhouden, belast zou worden met het vertalen en uitgeven der douanetarieven van alle landen. Een desbetreffend voorstel werd door het Kabinet te Brussel ter beoordeeling aan de verschillende handeldrijvende Staten gezonden en aanvankelijk niet ongunstig ontvangen.

De meeste Staten verklaarden zich in beginsel met het 
voorstel te kummen vereenigen; enkele slechts betwijfeliken het nut der instelling waaronder China en Japan, omdat hunne tarieven aan geene wijziging onderhevig zijn, dc Oranje-Vrijstaat die het geheel zonder douane-wetgeving stelt, hetgeen den kroniekschrijver van het Journal des Economistes doet uitroepen (trop heureux État d'Orange!), en onder de Europeesche mogendheden Frankrijk en Duitschland, die meenen dat de bestaande publicaties voldoende in de behoefte voorzien.

Eene conferentie, waaraan 26 afgevaardigden van 23 Staten deelnamen ${ }^{1}$ ) ter bespreking van het Belgische voorstel, werd den 15den Maart 1l. te Brussel gehouden.

De gevoerde beraadslagingen leidden tot het vaststellen van eene Ontwerp-Conventie en Reglement ter uitvoering, waarbij in hoofdzaak het volgende is bepaald:

a. Tusschen Belgie en alle landen die in het vervolg. tot de tegenwoordige Conventie zullen toetreden, wordt cene Vereeniging gevormd onder den naam van «Union Internationale pour la publication des tarifs douaniers, )

b. Het doel der Unie is om voor gemeenschappelijke rekening zoo spoedig en volledig mogelijk uittegeven de douanetarieven der verschillende landen en de wijzigingen die zij ondergaan.

c. Tot dat doel zal te Brussel een Internationaal Bureau worden opgericht belast met het vertalen en uitgeven dier tarieven, alsmede der wettelijke en administratieve beschikkingen die er wijzigingen in zullen brengen.

d. Deze uitgave zal geschieden door middel van een recueil getiteld: ) Bulletin international des douanes (Organe de l'Union internationale pour la publication des tarifs douaniers).»

1) Deze waren : de Argentijusche Republiek, Belgie, Chili, Cougu, CustaRica, Denemarken, Spanje, Vereenigde Staten van Noord-Amerika, GrootBritannie, Griekenland, Haïti, Hawaii-eilauden, Italie, Mexioo, NieuwZeeland, Portugal, Queensland, Rumenio, Rusland, Salvador, Servie, Zwitserland en Victoria. 
Volgens het ontworpen reglement ter uitvoering zal het «Bulletin» worden uitgegeven in vijf talen nl. in het Duitsch, Engelsch, Spaansch, Fransch en Italiaansch.

De verschillende uitgaven door het Bureau in het licht gegeven, zullen het eigendom van de Vereeniging zijn, het maken van afdrukken of uittreksels zal dan ook niet geoorloofd zijn, alleen dien Staten die deel uitmaken van de (Unie» en in wier landstaal het (Bulletin) niet verschijnt zal vergund zijn het geheel of gedeeltelijk, voor eigen rekening in die taal te doen overzetten.

Bovendien zal elke Staat der Vereeniging het recht hebben eenvoudige uittreksels der tarieven, of in bijzondere gevallen gedeelten van het (Bulletin), hetzij in eenig locaal officieel orgaan of in zijne parlementaire stukken te doen opnemen. Voorts is in het ConceptReglement de bepaling opgenomen dat het Bureau geen abonnementen zal kunnen leveren dan aan de regeeringen der landen die deel uitmaken van de Unie.

Terugkeerende tot de ontworpen Conventie vinden we daarin nog bepaald dat het personeel van het (Bureau» door de zorg van het Belgisch Ministerie van Buitenlandsche Zaken benoemd zal worden, dat tevens toe zal zien op den geregelden gang van zaken der instelling; dat jaarlijks aan de toegetreden mogendheden een verslag zal worden uitgebracht aangaande de werkzaamheden en den financieelen toestand van het Internationaal Bureau; dat een reglement van uitvoering zal bepalen de wijze van uitgave van het Bulletin en al wat betrekking heeft op de begrooting van het Bureau, de verdeeling der kosten onder de deelnemende mogendheden en de inwendige inrichting van den dienst; terwijl mede is voorgesteld de .overeenkomst voor den tijd van zeven jaren aan te gaan.

De kosten zullen jaarlijks 125,000 frcs. niet mogen overschrijden.

Ten einde de instẹlling in staat te stellen het «Bulletin») zoo nauwkeurig mogelijk te bewerken zullen de 
deelnemende partijen zoo spoedig mogelijk twee exemplaren toezenden:

a. van haar douanewetgeving en douanetarief, tot den dag bijgewerkt.

b. van alle beschikkingen die er in het vervolg wijziging in zullen brengen.

c. van alle aanschrijvingen en instructies aan de douaneambtenaren te geven (voor zooverre die gepubliceerd mogen worden) betreffende de toepassing van het tarief of de classificatie der goederen.

d. van hare tractaten, internationale overeenkomsten en binnenlandsche wetten die betrekking hebben op de van kracht zijnde tarieven.

Ten slotte zij de bepaling nog vermeld dat de Staten die aan de Conventie geen deel hebben genomen, later zullen kunnen toetreden.

Het plan der Belgische Regeering verdient zeker in vele opzichten toejuiching; de douanetarieven en de menigvuldige daarmede samenhangende voorschriften belemmeren in niet geringe mate het internationaal verkeer, maar ook onbekendheid met al die bepalingen baar't menigmaal teleurstellingen en nadeel, elke poging om aan dat bezwaar tegemoet te komen, mag derhalve met instemming worden begroet. Het is dan ook begrijpelijk dat het Belgische plan in beginsel vrij algemeen met sympathie werd ontvangen, maar het nut dat de handel van het Bureau zal trekken hangt geheel af van de wijze waarop het plan wordt uitgevoerd en daaromtrent kan men zich voorshands nog geen juist denkbeeld vormen.

De ontworpen Conventie spreekt van uitgeven, vertalen en bijwerken der douanetarieven; het reglement bepaalt in welke talen dat zal geschieden, dat niet dan onder bepaalde voorwaarden uittreksels of nadrukken mogen worden gemaakt, dat het Bureau slechts abonnementen zal kunnen leveren aan toegetreden Regeeringen, maar 
omtrent de wijzc van bewerking, in welken vorm de verzamelde stof het licht zal zien, zoekt men vruchteloos eenige aanwijzing.

Vertalen en uitgeven, moet men daaruit alleiden lat het de bedoeling is de douanetarieven en de daarop betrekking hebbende voorschriften - van ongeveer 80 Staten - in één bundel te vereenigen? Voorzeker zal daardoor het bestudeeren der verschillende tariefwetgevingen gemakkelijker gemaakt worden, maar in dien vorm uitgegeven zal het practisch nut dat de handel er van trekt, gering zijn.

De handelaar moet gemakkelijk kunnen zien, met welk bedrag zijn artikel in een bepaald land getroffen wordt, in verband met hetgeen zijne vreemde concurrenten daarvoor betalen, zonder in elk voorkomend geval een' lijvigen bundel tarieven, tractaten en voorschriften te moeten bestudeeren.

Om een ander voorbeeld te noemen, eene mededeeling omtrent het sluiten of opzeggen van een handelstractaat tusschen twee mogendheden zal alleen dan voor hem nut hebben, wanneer tevens daarbij wordt vermeld welke gevolgen daaruit, krachtens de door zijne regeering gesloten handelsovereenkomsten, voortvloeien.

Verschillende wijzen van bewerking zullen natuurlijk gevolgd kunnen worden, omtrent de vraag welke de beste en meest practische is, mag men verwachten dat de meeningen zeer uiteen zullen loopen, daarom ware het evenwel wenschelijk geweest dat bij de gevoerde beraadslagingen ook dit punt ter sprake ware gekomen en van verschillende zijden bezien.

Nog eene andere bepaling zal zeker de aandacht trekken en wel deze dat abonnementen op het uittegeven (Bulletin» alleen aan deelnemende Regeeringen verstrekt kunnen worden. Blijkbaar is deze bepaling ingelascht met de bedoeling om te voorkomen dat Gouvernementen die hunne medewerking aan de oprichting van het Bureau 
onthielden zonder nocmenswaarilige opofferingen er de vruchten van zouden plukken; maar van eene andere zijce, wil de instelling aan haar doel beantwoorden dan zal het noodig zijn dat de Regeeringen de publicaties van het Bureau gemakkelijk verkrijgbaar stellen; maar hoe dan te maken dat geen exemplaren aan of voor een vreemdeling, onderdaan van een niet toegetreden Staat, verkocht worden?

De Belgische Regeering hoopt in September a. s. eenc nieuwe bijeenkomst te doen plaats hebben, wellicht wordt dan de wijze van uitvoering meer in onderdeelen besproken en vastgesteld en zal daardoor het practische nut der instelling meer in het licht treden.

Mogen de handeldrijvende mogendheden alsdan talr ijk vertegenwoordigd zijn en het onderling overleg den weg openen tot de toetreding van die Staten, die tot dusverre slechts in beginsel hunne instemming betuigden.

Vowbury, Juni 1888.

S. van Citters. 